\title{
Effects of Chromium Supplementation on Growth Rate and Metabolism in Fattening Bulls
}

\author{
A. PECHOVÁ, J. ILLEK, M. ŠINDELÁŘ, L. PAVLATA \\ Clinic of Ruminant Diseases, University of Veterinary and Pharmaceutical Sciences, Brno, Czech Republic
}

Received June 18, 2001

Accepted November 18, 2002

\section{Abstract}

Pechová A., J. Illek, M. Šindelář, L. Pavlata: Effects of Chromium Supplementation on Growth Rate and Metabolism in Fattening Bulls. Acta Vet Brno 2002, 71: 535-541.

Effects of chromium supplementation on growth rate and selected metabolic indexes including interactions with trace elements (zinc, copper) were investigated in 8-month-old bulls divided into one experimental $(\mathrm{E}, n=8)$ and one control $(\mathrm{C}, n=9)$ groups with mean live weights $284.9 \pm 33.9$ and $279.6 \pm 27.0 \mathrm{~kg}$, respectively. The experimental group was fed a diet supplemented with chromium-enriched yeasts (Co-Factor III Chromium Yeast, Alltech, $0.1 \% \mathrm{Cr}^{3+}$ ) at a dose corresponding to the intake of $5 \mathrm{mg}$ of $\mathrm{Cr}$ per animal per day in the first phase (up to day 136) and 8 g per animal per day in the second phase (days 136 to 220) of the fattening period. The bulls were weighed and blood samples were collected on days 1, 136 and 220 of the experimental period. Favourable effects of chromium supplementation were evident from higher weight gains in the first fattening phase $(1.04 \pm 0.12 \mathrm{vs} .0 .82 \pm 0.12 \mathrm{~kg} ; p \leq 0.01)$. The between-group difference diminished and became now significant in the second phase of the fattening period $(0.82 \pm 0.12$ vs. $0.74 \pm 0.14 \mathrm{~kg}$ ).

Significantly higher concentration of protein $(p \leq 0.01)$ on days 136 and 220, total cholesterol $(p \leq 0.05)$ on day 136, copper $(p \leq 0.05)$ on days 136 and 220, and significantly lower concentration of magnesium $(p \leq 0.05)$ on day 220 , phosphorus $(p \leq 0.05)$ on day 136 was found in experimental group. No effects of chromium supplementation on the concentrations of glucose, urea, sodium, potassium, zinc, AST, GMT, LD, ALP, and CK were observed.

Chromium, metabolic profile, cattle

Chromium is a transitional element involved in many oxidative events. The topics of interest are its essentiality and toxicity. The interest in chromium as an essential element has grown in the recent years (Lindemann 1998). Biologically active are $\mathrm{Cr}^{3+}$ and $\mathrm{Cr}^{6+}$, but some differences in their metabolism are known. $\mathrm{Cr}^{6+}$ is more readily absorbed than $\mathrm{Cr}^{3+}$, but its toxicity is higher. Therefore, more information on $\mathrm{Cr}^{3+}$ is available.

Chromium can be involved in several biological functions. However, its major role seems to be enhancement of the action of insulin. Chromium, as an integral component of the Glucose Tolerance Factor (GTF), binds insulin, which is responsible for the transport of glucose and amino acids into the cell, to cell membrane receptors. Such optimisation of insulin activity results in improved regulation of glucose intake by cells and thereby in a better control of blood glucose concentration and maximum utilization of the energetic potential.

Chromium ranks with essential elements in humans and animals. Clinical manifestations of chromium deficiency have been summarised by Anderson et al. (1994) as follows: starvation hyperglycaemia, impaired glucose tolerance, increased concentration of circulating insulin, glycosuria, increased concentrations of cholesterol and triacylglycerols in blood serum, decreased concentration of bound insulin, and decrease in the number of insulin receptors. Supplementation with chromium is indicated particularly in animals exposed to strain. Results of recent experiments undertaken by North American scientists in pigs, cattle, horses and poultry have shown that chromium improves carcass quality by

Address for correspondence:

MVDr. A. Pechová, CSc

Clinic of Ruminant Diseases

University of Veterinary and Pharmaceutical Sciences

Palackého 1-3,612 42 Brno, Czech Republic
Phone: +420 541562408

email: pechovaa@ vfu.cz

http://www.vfu.cz/acta-vet/actavet.htm 
increasing meatiness and decreasing the fat content (Lindemann et al. 1995; Boleman et al. 1995; Money and Cromwell 1995), and increases (Page et al. 1993; MoonsieShageer and Mowat 1993) and improves the efficacy of feed utilisation (Lindemann et al. 1995). Further, a decrease in corticosteroid and cholesterol concentrations and also enhancement of immune responses to vaccination were described in subjects receiving chromium-supplemented rations (Burton et al. 1993; Chang et al. 1996; Mowat et al. 1993). It must be noted, however, that the results of the individual authors are not consistent, apparently due to a strong dependence on other factors, such as growth phase, stress, contents of lysine, niacin, and saccharides in the ration, and level of chromium supply.

The objective of our experiment was to establish the effects of chromium supplementation on growth rate in bulls and selected metabolic indexes including the interaction with the trace elements zinc and copper.

\section{Materials and Methods}

The experiment was carried out in fattening bulls of a herd of Black Pied Lowland cattle in 1998 on the agricultural farm in Czech-Moravian Highland. Eight-month-old bulls were divided into an experimental (E, $n=$ $8)$ and a control $(\mathrm{C}, n=9)$ groups. Mean live weights in the experimental and the control groups were 284.9 \pm 33.9 $\mathrm{kg}$ and $279.6 \pm 27.0 \mathrm{~kg}$, respectively. The bulls were fed a following ration: maize silage, clover-grass silage and concentrate. The mixture of concentrate contained wheat $40 \%$, barley $27 \%$, extract of rape-seed $15 \%$, extract of soya bean $1 \%$, minerals $3 \%$ ). The characterisation of the ration according fattening period is in the Table 1 . The ration of the experimental group was supplemented with organic chromium in the form of chromium-enriched yeast (Co-Factor III Chromium Yeast, Alltech, $0.1 \% \mathrm{Cr}^{3+}$ ) at a dose corresponding to the intake of $5 \mathrm{mg} \mathrm{Cr}$ per animal per day in the first phase (up to day 136) and $8 \mathrm{mg} \mathrm{Cr}$ per animal per day in the second phase (days 137 to 220) of the fattening period. The bulls were weighed and blood samples were collected from $\mathrm{v}$. jugularis at the beginning of the experiment and on days 136 and 220.

Blood plasma was analysed for the concentrations of some biochemical parameters. The analyses for total proteins, glucose, urea, cholesterol, triacylglycerols, AST (aspartate aminotransferase), GMT (gammaglutamyltransferase), CK (creatin kinase), LD (lactate dehydrogenase), ALP (alkaline phosphatase), and inorganic phosphorus were done using the automatic analyser Cobas Mira, and the minerals sodium, potassium, calcium, magnesium, zinc, and copper were determined by atomic absorption spectroscopy using the apparatus Hilger 1500 .

The obtained data were processed by the F-test for the assessment of variations in the individual sets and, in dependence on results, by the double-tailed Student $t$-test for sets with equal/unequal variations using the EXCEL software. Statistical evaluation of obtained data is in the tables as mean (x) and standard deviation (SD).

Table 1

Daily ration for bulls at the beginning of the first and second fattening period and at the end of the experiment

\begin{tabular}{|c|c|c|c|c|}
\hline \multicolumn{2}{|l|}{ Days } & 1 & 137 & 220 \\
\hline Maize silage & {$\left[\mathrm{kg} \cdot \mathrm{day}^{-1}\right]$} & 9.0 & 17 & 20 \\
\hline Clover-grass silage & {$\left[\mathrm{kg} \cdot \mathrm{day}^{-1}\right]$} & 4.5 & 8.5 & 10 \\
\hline Concentrate & {$\left[\mathrm{kg} \cdot \mathrm{day}^{-1}\right]$} & 3.0 & 3.0 & 3.0 \\
\hline Dry matter & {$\left[\mathrm{kg} \cdot \mathrm{day}^{-1}\right]$} & 6.6 & 10.2 & 11.5 \\
\hline Crude protein & {$\left[\mathrm{kg} \cdot \mathrm{day}^{-1}\right]$} & 1.0 & 1.4 & 1.5 \\
\hline Net energy & {$\left[\mathrm{MJ} \cdot \mathrm{day}^{-1}\right]$} & 34.0 & 54.0 & 60.0 \\
\hline Crude fibre & {$\left[\mathrm{kg} \cdot \mathrm{day}^{-1}\right]$} & 1.1 & 2.0 & 2.4 \\
\hline Fat & {$\left[\mathrm{kg} \cdot \mathrm{day}^{-1}\right]$} & 0.2 & 0.3 & 0.3 \\
\hline Sodium & {$\left[\mathrm{g} \cdot \mathrm{day}^{-1}\right]$} & 6 & 6 & 6 \\
\hline Potassium & {$\left[\mathrm{g} \cdot \mathrm{day}^{-1}\right]$} & 84 & 140 & 161 \\
\hline Calcium & {$\left[\mathrm{g} \cdot \mathrm{day}^{-1}\right]$} & 35 & 50 & 56 \\
\hline Phosphorus & {$\left[\mathrm{g} \cdot \mathrm{day}^{-1}\right]$} & 31 & 41 & 45 \\
\hline Magnesium & {$\left[\mathrm{g} \cdot \mathrm{day}^{-1}\right]$} & 20 & 27 & 29 \\
\hline Zinc & {$\left[\mathrm{mg} \cdot \mathrm{day}^{-1}\right]$} & 757 & 757 & 757 \\
\hline Copper & {$\left[\mathrm{mg} \cdot \mathrm{day}^{-1}\right]$} & 268 & 268 & 268 \\
\hline
\end{tabular}




\section{Results and Discussion}

\section{Growth rate}

The experiment demonstrated favourable effects of chromium supplementation on growth rate in bulls. The difference in weight gains between the experimental and the control bulls was highly significant in the first phase of the fattening period, but diminished to become no significant in the second phase. Weight gains for the individual phases are presented in Table 2 and growth dynamics are shown in Table 3.

\section{Table 2}

Mean weight gains (mean \pm SD) of bulls during the experimental period in the experimental $(E ; n=8)$ and control $(\mathrm{C} ; \mathrm{n}=9)$ group

\begin{tabular}{|c|c|c|c|}
\hline Days & $1-136$ & $137-220$ & $1-220$ \\
\hline $\begin{array}{c}\mathrm{C} \\
{\left[\mathrm{kg} \cdot \mathrm{day}^{-1}\right]}\end{array}$ & $0.82 \pm 0.12$ & $0.74 \pm 0.14$ & $0.79 \pm 0.11$ \\
\hline $\begin{array}{c}\mathrm{E} \\
{\left[\mathrm{kg} \cdot \mathrm{day}^{-1}\right]}\end{array}$ & $1.04 \pm 0.12$ & $0.82 \pm 0.12$ & $0.95 \pm 0.11$ \\
$* *$
\end{tabular}

$* * p \leq 0.01$ (between-group difference)

Table 3

Mean weight (mean $\pm \mathrm{SD}$ ) of bulls during the experimental period in the experimental $(\mathrm{E} ; \mathrm{n}=8)$ and control $(\mathrm{C} ; \mathrm{n}=9)$ group

\begin{tabular}{|c|c|c|c|}
\hline Days & 1 & 137 & 220 \\
\hline $\begin{array}{c}\mathrm{C} \\
{[\mathrm{kg}]}\end{array}$ & $279.56 \pm 27.04$ & $390.44 \pm 36.26$ & $452.33 \pm 38.05$ \\
\hline $\mathrm{E}$ & $284.88 \pm 33.91$ & $426.13 \pm 36.41$ & $494.75 \pm 37.87$ \\
{$[\mathrm{~kg}]$} & & & $*$ \\
\hline
\end{tabular}

$* p \leq 0.05$ (between-group difference)

The difference in the first phase was apparently associated with a stronger stress to which the bulls were exposed and which resulted from relocation into new premises, a change in the epizootiological situation, and changes in social ranking within the newly formed groups. Considering the higher demand for chromium in animals exposed to stress (Lindemann 1996) and a lower stress susceptibility in subjects receiving chromium supplements (Kegley and Spears 1995; Moonsie-Shageer and Mowat 1993), we can assume that just these mechanisms were responsible for the difference in the effects of chromium on weight gains in the first and the second phase of the fattening period. Similar results were reported by Chang et al. (1995) who also observed weaker effects of chromium combined with nicotinic acid on weight gains after day 28 of their experiment. The growth rate can be influenced also by favourable effects of chromium on the state of health and immunity as described by Mowat et al. (1993). Increased weight gains in animals fed a chromium-supplemented ration were also reported by Mowat et al. (1993) and Kegley et al. (1997) for calves and Bonomi et al. (1998) for heifers. On the other hand, no effects of chromium on weight gains in fattened bulls were found by Daniels s on and Pehrson (1998) and Mathison and Engstrom (1995).

\section{Metabolic profile}

Significant between-group differences were observed in the concentrations of total protein (at $2^{\text {nd }}$ and $3^{\text {rd }}$ sampling), total cholesterol (at $2^{\text {nd }}$ sampling), phosphorus (at $2^{\text {nd }}$ 
Table 4

Selected indexes of metabolic profiles (mean \pm SD) in blood plasma during the experimental period in control $(\mathrm{C} ; \mathrm{n}=9)$ and experimental $(\mathrm{E} ; \mathrm{n}=8)$ bulls

\begin{tabular}{|c|c|c|c|c|}
\hline Days & & 1 & 136 & 220 \\
\hline $\begin{array}{l}\text { Total protein } \\
{\left[\mathrm{g} \cdot \mathrm{l}^{-1}\right]}\end{array}$ & $\begin{array}{l}\mathrm{C} \\
\mathrm{Cr}\end{array}$ & $\begin{array}{l}66.03 \pm 4.07 \\
67.16 \pm 5.21\end{array}$ & $\begin{array}{l}77.31 \pm 3.48 \\
82.40 \pm 2.98^{* *}\end{array}$ & $\begin{array}{l}64.09 \pm 4.96 \\
71.35 \pm 4.07 * *\end{array}$ \\
\hline $\begin{array}{c}\text { Glucose } \\
{\left[\mathrm{mmol}^{-1} \mathrm{l}^{-1}\right]}\end{array}$ & $\begin{array}{l}\mathrm{C} \\
\mathrm{E}\end{array}$ & $\begin{array}{l}4.81 \pm 0.48 \\
4.53 \pm 0.22\end{array}$ & $\begin{array}{l}4.97 \pm 0.37 \\
4.96 \pm 0.40\end{array}$ & $\begin{array}{l}4.24 \pm 0.14 \\
4.13 \pm 0.30\end{array}$ \\
\hline $\begin{array}{c}\text { Urea } \\
{\left[\mathrm{mmol} \cdot \mathrm{I}^{-1}\right]}\end{array}$ & $\begin{array}{l}\mathrm{C} \\
\mathrm{E}\end{array}$ & $\begin{array}{l}3.72 \pm 0.79 \\
3.47 \pm 0.58\end{array}$ & $\begin{array}{l}3.09 \pm 0.94 \\
2.60 \pm 0.42\end{array}$ & $\begin{array}{l}4.44 \pm 0.53 \\
4.11 \pm 0.66\end{array}$ \\
\hline $\begin{array}{c}\text { ALP } \\
{\left[\mu \mathrm{kat} \cdot \mathrm{I}^{-1}\right]}\end{array}$ & $\begin{array}{l}\mathrm{C} \\
\mathrm{E}\end{array}$ & $\begin{array}{l}2.59 \pm 0.42 \\
3.09 \pm 0.81\end{array}$ & $\begin{array}{l}3.91 \pm 1.00 \\
4.27 \pm 1.12\end{array}$ & $\begin{array}{l}2.53 \pm 0.78 \\
2.71 \pm 0.59\end{array}$ \\
\hline $\begin{array}{c}\text { AST } \\
{\left[\mu \mathrm{kat} \cdot \mathrm{I}^{-1}\right]}\end{array}$ & $\begin{array}{l}\mathrm{C} \\
\mathrm{E}\end{array}$ & $\begin{array}{l}1.17 \pm 0.12 \\
1.28 \pm 0.20\end{array}$ & $\begin{array}{l}1.35 \pm 0.23 \\
1.35 \pm 0.17\end{array}$ & $\begin{array}{l}1.32 \pm 0.12 \\
1.38 \pm 0.20\end{array}$ \\
\hline $\begin{array}{c}\mathrm{CK} \\
{\left[\mu \mathrm{kat} \cdot \mathrm{I}^{-1}\right]}\end{array}$ & $\begin{array}{l}\mathrm{C} \\
\mathrm{E}\end{array}$ & $\begin{array}{l}2.48 \pm 0.62 \\
2.81 \pm 0.50\end{array}$ & $\begin{array}{l}2.44 \pm 0.54 \\
2.78 \pm 0.75\end{array}$ & $\begin{array}{l}2.16 \pm 1.39 \\
2.31 \pm 1.14\end{array}$ \\
\hline $\begin{array}{c}\text { GMT } \\
{\left[\mu \mathrm{kat} \cdot \mathrm{l}^{-1}\right]}\end{array}$ & $\begin{array}{l}\mathrm{C} \\
\mathrm{E}\end{array}$ & $\begin{array}{l}0.34 \pm 0.05 \\
0.36 \pm 0.07\end{array}$ & $\begin{array}{l}0.32 \pm 0.05 \\
0.34 \pm 0.06\end{array}$ & $\begin{array}{l}0.35 \pm 0.07 \\
0.34 \pm 0.07\end{array}$ \\
\hline $\begin{array}{c}\text { LD } \\
{\left[\mu \mathrm{kat} \cdot \mathrm{l}^{-1}\right]}\end{array}$ & $\begin{array}{l}\mathrm{C} \\
\mathrm{E}\end{array}$ & $\begin{array}{l}37.6 \pm 2.20 \\
38.5 \pm 3.38\end{array}$ & $\begin{array}{l}38.3 \pm 4.53 \\
36.6 \pm 3.41\end{array}$ & $\begin{array}{l}44.8 \pm 3.86 \\
44.8 \pm 4.67\end{array}$ \\
\hline $\begin{array}{c}\text { Total cholesterol } \\
{\left[\mathrm{mmol} \cdot \mathrm{l}^{-1}\right]}\end{array}$ & $\begin{array}{l}\mathrm{C} \\
\mathrm{E}\end{array}$ & $\begin{array}{l}2.11 \pm 0.32 \\
2.51 \pm 0.49\end{array}$ & $\begin{array}{c}2.06 \pm 0.24 \\
2.40 \pm 0.31 *\end{array}$ & $\begin{array}{l}1.96 \pm 0.32 \\
2.22 \pm 0.39\end{array}$ \\
\hline $\begin{array}{c}\text { Triacylglycerols } \\
{\left[\mathrm{mmol} \cdot \mathrm{l}^{-1}\right]}\end{array}$ & $\begin{array}{l}\mathrm{C} \\
\mathrm{E}\end{array}$ & $\begin{array}{l}0.26 \pm 0.07 \\
0.26 \pm 0.04\end{array}$ & $\begin{array}{l}0.14 \pm 0.04 \\
0.11 \pm 0.06\end{array}$ & $\begin{array}{l}0.23 \pm 0.05 \\
0.25 \pm 0.03\end{array}$ \\
\hline
\end{tabular}

$* p \leq 0.05$ (between-group difference)

$* * p \leq 0.01$ (between-group difference)

sampling), magnesium (at $3^{\text {rd }}$ sampling), and copper (at $2^{\text {nd }}$ and $3^{\text {rd }}$ sampling). Selected values of the metabolic profile in the experimental and the control groups are shown in Tables 4 and 5.

Analyses for nitrogenous substances demonstrated a significantly higher concentration of total blood plasma proteins at $2^{\text {nd }}$ and $3^{\text {rd }}$ sampling and a no significantly lower concentration of urea in the experimental group throughout the experimental period. We assume that the differences were due to the more intensive proteosynthesis and a lesser amount of residual nitrogen, which is detoxified in the liver within the ureasynthetic cycle. This finding is in agreement with the known mechanism of action of chromium consisting in the improvement of amino acid entry into and proteosynthesis in muscular cells (Evans and Bowman 1992).

No significant between-group differences were found in indexes of energy metabolism. The glucose concentration was relatively high varying between 4 and $5 \mathrm{mmol} \cdot \mathrm{l}^{-1}$, which is a moderate increase above the physiological range of 3.0 to $3.9 \mathrm{mmol}^{-1} \mathrm{l}^{-1}$ (V rzgula et al. 1987). The glucose concentration was largely ration-dependent and was not influenced by chromium supplementation. To a certain extent, this finding contradicts the presumed role of chromium in the GTF, which moderates the fluctuation of glycaemia and enhances glucose catching by cells. However, the range of glycaemia, which is influenced by chromium, is also important in considerations on the mechanism of action. A certain role might be played by the content of dietary nicotinic acid, which influences the responsiveness 
of the organism to chromium supplementation (Urberg and Zemel 1987). Absence of effect of chromium on glycaemia in calves was reported also by Bunting et al. (1994).

A significance between-group difference was also found in the concentration of total cholesterol, which was lower in the control than in the experimental group on day 136. Since some difference was observed already at the beginning of the experiment, it can be interpreted rather as an individual characteristic of the randomly formed groups than as an effect of chromium supplementation, which became apparent in the course of the experiment only.

Enzyme profile was monitored throughout the experiment to detect possible adverse effects of chromium. A high safety of chromium was demonstrated by the absence of any deviations from normal values. No signs of toxicity were observed in humans receiving up to $1 \mathrm{mg}$ of $\mathrm{Cr}^{3+}$ per day (Barceloux 1999).

Certain differences between the experimental and the control groups were found also in the metabolism of minerals. Compared with controls, the experimental group showed significantly lower concentrations of phosphorus at $2^{\text {nd }}$ sampling and of magnesium at $3^{\text {rd }}$ sampling. These differences are rather difficult to explain, because each of them was found at one sampling only and none of the values exceeded the physiological range. Both phosphorus and magnesium are closely associated with energy metabolism and the low blood concentrations may have been due to a higher demand in animals with a higher growth rate. The marked decrease in the phosphorus concentration at $2^{\text {nd }}$ sampling was reflected also in increased activity of ALP in both groups which was indicative of an alteration in bone tissue due apparently to phosphorus deficiency. Published data on alterations in mineral metabolism in animals fed a diet supplemented with chromium is rather scarce. MoonsieShageer and Mowat (1993) observed an only temporal increase of calcium and magnesium concentrations in calves.

Interesting data resulted also from the monitoring of trace element concentrations. Compared with the experimental group, copper concentration in blood plasma of controls was significantly lower. The concentration decreased throughout the experimental period. While the difference between $2^{\text {nd }}$ and $3^{\text {rd }}$ sampling was significant $(p \leq 0.05)$ in the control

Table 5

Selected indexes of blood plasma mineral profile $($ mean \pm SD) of control $(C ; n=9)$ and experimental $(E ; n=8)$

\begin{tabular}{|c|c|c|c|c|}
\hline \multicolumn{2}{|c|}{ Days } & 1 & 136 & 220 \\
\hline $\mathrm{Na}$ & $\mathrm{C}$ & $144.7 \pm 0.94$ & $143.4 \pm 2.63$ & $143.3 \pm 2.00$ \\
{$\left[\mathrm{mmol} \cdot \mathrm{I}^{-1}\right]$} & $\mathrm{E}$ & $144.9 \pm 2.26$ & $145.8 \pm 1.39$ & $144.3 \pm 1.71$ \\
\hline $\mathrm{K}$ & $\mathrm{C}$ & $4.35 \pm 0.30$ & $4.23 \pm 0.17$ & $3.89 \pm 0.24$ \\
{$\left[\mathrm{mmol} \cdot \mathrm{I}^{-1}\right]$} & $\mathrm{E}$ & $4.18 \pm 0.19$ & $4.28 \pm 0.18$ & $4.02 \pm 0.22$ \\
\hline $\mathrm{Ca}$ & $\mathrm{C}$ & $2.48 \pm 0.19$ & $2.52 \pm 0.10$ & $2.68 \pm 0.15$ \\
{$\left[\mathrm{mmol} \cdot \mathrm{I}^{-1}\right]$} & $\mathrm{E}$ & $2.52 \pm 0.27$ & $2.59 \pm 0.15$ & $2.63 \pm 0.11$ \\
\hline $\mathrm{P}$ & $\mathrm{C}$ & $2.50 \pm 0.32$ & $2.26 \pm 0.16$ & $2.90 \pm 0.15$ \\
{$\left[\mathrm{mmol} \cdot \mathrm{l}^{-1}\right]$} & $\mathrm{E}$ & $2.61 \pm 0.23$ & $2.07 \pm 0.14^{*}$ & $2.92 \pm 0.27$ \\
\hline $\mathrm{Mg}$ & $\mathrm{C}$ & $0.86 \pm 0.05$ & $0.83 \pm 0.03$ & $0.94 \pm 0.05$ \\
{$\left[\mathrm{mmol} \cdot \mathrm{I}^{-1}\right]$} & $\mathrm{E}$ & $0.82 \pm 0.05$ & $0.82 \pm 0.03$ & $0.88 \pm 0.04^{*}$ \\
\hline $\mathrm{Cu}$ & $\mathrm{C}$ & $16.05 \pm 2.09$ & $15.94 \pm 1.50$ & $13.62 \pm 1.69$ \\
{$\left[\mu \mathrm{mol} \cdot \mathrm{I}^{-1}\right]$} & $\mathrm{E}$ & $17.27 \pm 1.66$ & $17.48 \pm 1.12^{*}$ & $11.66 \pm 1.34$ \\
\hline $\mathrm{Zn}$ & $\mathrm{C}$ & $11.58 \pm 2.66$ & $11.71 \pm 0.90$ & $11.72 \pm 1.00$ \\
\hline$\left[\mu \mathrm{mol} \cdot \mathrm{I}^{-1}\right]$ & E & $11.27 \pm 1.97$ & $11.69 \pm 0.96$ & \\
\hline
\end{tabular}

$* p \leq 0.05$ (between-group difference) 
group, the decrease was less marked in the experimental group and the differences between samplings were non-significant. Interactions among trace elements are very complex and only few relevant data is available. Interactions of copper with zinc, selenium, cadmium, mercury, lead, and iron were investigated, but little is known about relations between copper and chromium. Zinc concentration remained constant during the experimental period indicating the absence of effects of chromium supplementation.

\section{Vliv dotace chromu na intenzitu růstu a metabolismus býků ve výkrmu}

Byl realizován pokus s cílem sledování vlivu dotace Cr na růst býků a vybrané parametry metabolismu včetně interakcí se stopovými prvky $(\mathrm{Zn}, \mathrm{Cu})$.

Ve výkrmně býků byly vytvořeny dvě skupiny - pokusná ( 8 ks) a kontrolní ( 9 ks), kam byli zařazeni býci ve stáŕi 8 měsíců. Průměrná živá hmotnost býků pokusné skupiny byla $284,9 \pm 33,9 \mathrm{~kg}$ a kontrolní skupiny 279,6 $\pm 27,0 \mathrm{~kg}$. Býkům pokusné skupiny byl podáván chrom $\mathrm{v}$ dávce $5 \mathrm{mg} / \mathrm{kus} / \mathrm{den} \mathrm{v}$ první fázi výkrmu (136 dnů) a ve druhé fázi výkrmu (137 220 dní) v dávce $8 \mathrm{mg} / \mathrm{kus} / \mathrm{den} \mathrm{v}$ organické formě Cr-kvasinek (Co-Factor III Chromium Yeast, Alltech, $0,1 \% \mathrm{Cr}^{3+}$ ). $\mathrm{V}$ průběhu pokusu byla sledována hmotnost býků vážením a byla odebírána krev na biochemické vyšetření.

Byl prokázán pozitivní vliv dotace chromu na růst býků. Dotace chromu ovlivnila pozitivně výši prŕirůstků $(p \leq 0,01)$ v první fázi výkrmu $(1,04 \pm 0,12$ vs. $0,82 \pm 0,12$ $\left.\mathrm{kg} \cdot \mathrm{den}^{-1}\right)$, ve druhé fázi výkrmu rozdíly mezi pokusnou a kontrolní skupinou nebyly signifikantní $\left(0,82 \pm 0,12\right.$ vs. $\left.0,74 \pm 0,14 \mathrm{~kg} \cdot \mathrm{den}^{-1}\right)$.

$\mathrm{V}$ metabolickém profilu byla u pokusné skupiny zjiššena signifikantně vyšší koncentrace ( $p \leq 0,01)$ celkové bílkoviny v krevní plazmě (136. den pokusu 82,4 $\pm 2,98$ vs. $77,31 \pm 3,48$ $\mathrm{g} \cdot \mathrm{l}^{-1}, 220$.den $71,35 \pm 4,07$ vs. $\left.64,09 \pm 4,96 \mathrm{~g} \cdot \mathrm{l}^{-1}\right)$. Koncentrace celkového cholesterolu byla signifikantně vyšší $(p \leq 0,05)$ u pokusné skupiny 136 . den $(2,40 \pm 0,31$ vs. $2,06 \pm 0,24$ $\left.\mathrm{mmol} \cdot \mathrm{l}^{-1}\right)$. Z minerálních látek byly zjišstěny v pokusné skupině nižší koncentrace $(p \leq 0,05)$ fosforu (136.den $2,07 \pm 0,14$ vs. $\left.2,26 \pm 0,16 \mathrm{mmol} \cdot \mathrm{l}^{-1}\right)$, hořčíku (220. den 0,88 $\pm 0,04$ vs. $\left.0,94 \pm 0,05 \mathrm{mmol} \cdot \mathrm{l}^{-1}\right)$ a naopak vyšší koncentrace $(p \leq 0,05)$ mědi $(136$. den $17,48 \pm 1,12$ vs. $15,94 \pm 1,50 \mu \mathrm{mol} \cdot \mathrm{l}^{-1}, 220$. den $15,79 \pm 2,15 \mathrm{vs}$. 13,62 $\left.\pm 1,69 \mu \mathrm{mol} \cdot \mathrm{l}^{-1}\right)$. Koncentrace glukózy, močoviny, AST, GMT, LD, ALP, CK, Na, K, Zn nebyly dotací chromu ovlivněny.

\section{Acknowledgements}

This work was supported by the Grant Agency of the Czech Republic, Project No. 507/95/0531.

\section{References}

ANDERSON, RA, LYONS, TP, JACQUES, KA 1994: Stress effects on chromium nutrition of humans and farm animals. In: Biotechnology in the feed industry: Proceedings of Alltech's Tenth Annual Symposium, pp. 267274

BARCELOUX, DG 1999: Chromium. Clin Toxicol 37:173-194

BOLEMAN, SL, BOLEMAN, SJ, BIDNER, TD, WARD, TL, SOUTHERN, LL, PONTIF, JE, PIKE, MM 1995: Effects of chromium picolinate on growth, body composition, and tissue accretion in pigs. J Anim Sci 73:20332042

BONOMI, A, QUARANTELLI, A, BONOMI, BM, SABBIONI, A, SUPERCHI, P, ORLANDI, A 1998: [Organic chromium in heifers feeding (experimental reports)] Rivista di Scienza dell'Alimentazione 27:137-148

BUNTING, LD, FERNANDEZ, JM, THOMPSON, DL, SOUTHERN, LL 1994: Influence of chromium propionate on glucose usage and metabolic criteria in g rowing Holstein calves. J Anim Sci 72:1591-1599

BURTON, JL, MALLARD, BA, MOWAT, DN 1993: Effects of supplemental chromium on immune responses of periparturient and early lactation dairy cows. J Anim Sci 71:1532-1539

DANIELSSON, DA, PEHRSON, B 1998: Effects of chromium supplementation on the growth and carcass quality of bulls fed a grain-based diet during the finishing period. J Vet Med A 45:219-224

EVANS, GW, BOWMAN, TD 1992: Chromium picolinate increases membrane fluidity and rate of insulin internalization. J Inorg Biochem 46:243-250

CHANG, X, MALLARD, BA, MOWAT, DN 1996: Effects of chromium on health status, blood neutrophil phagocytosis and in vitro lymphocyte blastogenesis of dairy cows. Vet Immunol Immunopathol 52:37-52 
CHANG, X, MOWAT, DN, MALLARD, BA 1995: Supplemental chromium and niacin for stressed feeder calves. Can J Anim Sci 75:351-358

CHANG, X, MOWAT, DN, SPIERS, GA 1992: Carcass characteristics and tissue mineral contents of steers fed supplemental chromium. Can J Anim Sci 72:663-669

KEGLEY, EB, SPEARS, JW 1995: Immune response, glucose metabolism and performance of stressed feeder calves fed inorganic or organic chromium. J Anim Sci 73:2721-2726

KEGLEY, EB, SPEARS, JW, BROWN, TT 1997: Effect of shipping and chromium supplementation on performance, immune response, and disease resistance of steers. J Anim Sci 75:1956-1964

LINDEMANN, MD 1996: Organic chromium - the missing link in Farm animal nutrition? Feeding times 1(3):816

LINDEMANN, MD 1998: Organic Chromium - an exciting beginning, a promising Future. In: Biotechnology in the Feed Industry, Proceedings of Alltech's $14^{\text {th }}$ Annual Symposium, pp.217-227

LINDEMANN, MD, WOOD, CM, HARPER, AF, KORNEGAY, ET, ANDERSON, RA 1995: Dietary chromium picolinate additions improve gain:feed and carcass characteristics in growing-finishing pigs and increase litter size in reproducing sows. J Anim Sci 73:457-465

MATHISON, GW, ENGSTROM, DF 1995: Chromium and protein supplements for growing-finishing beef steers fed barley-based diets. Can J Anim Sci 75:549-558

MOONEY, KW, CROMWELL, GL 1995: Effects of dietary chromium picolinate supplementation on growth, carcass characteristics and accretion rates of carcass tissues in growing-finishing swine. J Anim Sci 73:33513357

MOONSIE-SHAGER, S, MOWAT, DN 1993: Effect of level of supplemental chromium on performance, serum constituents, and immune status of stressed feeder calves. J Anim Sci 71:232-238

MOWAT, DN, CHANG, X, YANG, WZ 1993: Chelated chromium for stressed feeder calves. Can J Anim Sci 73:49-55

PAGE, TG, SOUTHERN, LL, WARD, TL, THOMPSON, DL 1993: Effect of chromium picolinate on growth and serum and carcass traits of growing-finishing pigs. J Anim Sci 71:656-662

URBERG, M, ZEMEL, MB 1987: Evidence for synergism between chromium and nicotinic acid in the control of glucose tolerance in elderly humans. Metabolism 36:896-899

VRZGULA, L et al. 1982: Poruchy látkového metabolizmu hospodárskych zvierat a ich prevencia. Príroda, 492 p. 